\title{
Pengaruh Temperatur Fluida Panas Masuk Terhadap Karakteristik Penukar Panas Shell and Tube
}

\author{
Cendy S.E Tupamahu ${ }^{1, *}$, Constantinus Narmo ${ }^{2}$ \\ 1Jurusan Teknik Mesin Fakultas Teknik Universitas Pattimura, Ambon 97233 \\ *cendy.tupamahu@fatek.unpatti.ac.id \\ 2Jurusan Studi Teknik Mesin Universitas Pattimura, Ambon 97233
}

\begin{abstract}
Abstrak Penukar panas yang sering digunakan dalam aplikasi rekayasa industri yakni tipe shell and tube. Laju aliran massa yang berada pada penukar panas juga mempengaruhi karakteristik daripada penukar panas tersebut. Semakin tinggi laju aliran massa berlawanan berati waktu kontak kedua fluida semakin singkat. Berangkat dari kondisi ini, disusun hipotesa bahwa kenaikan laju aliran massa berlawanan akan meningkatkan karakteristik suatu penukar panas. Eksperimen dilakukan untuk menganalisa pengaruh variasi temperatur masuk fluida panas pada kecepatan fluida konstan terhadap karakteristik perpindahan panas penukar panas tipe shell and tube. Penelitian ini diameter shell 4 inch dan diameter tube 3/8 inch dengan 8 laluan, Aliran fluida dingin mengalir dalam sisi shell dan aliran fluida panas mengalir dalam tube dengan laju aliran massa konstan $0.024 \mathrm{~m} / \mathrm{s}$ dengan variasi temperatur masuk fluida panas $\left(\mathrm{T}_{\mathrm{hi}}\right)$ adalah $323^{\circ} \mathrm{K}, 333^{\circ} \mathrm{K}, 343^{\circ} \mathrm{K}, 353^{\circ} \mathrm{K}, 363^{\circ} \mathrm{K}$. Peningkatan temperatur fluida panas masuk (Thi) dengan kecepatan (V) konstan mempengaruhi karakteristik penukar panas seperti bilangan Reynold (Red), bilangan Nusselt (Nud), koefisien konveksi (h), koefisien perpindahan panas menyeluruh (U), dan laju perpindahan panas (q) yang meningkat tidak signifikan pada (Thi) 363K dan min pada temperatur masuk fluida panas (Thi) $323 \mathrm{~K}$. (ع) penukar panas max pada Thi $323 \mathrm{~K}$ dan kemudian turun $1 \%$ pada Thi $353 \mathrm{~K}$.
\end{abstract}

Kata kunci: Penukar panas, shell and tube, variasi fluida panas masuk $\left(\mathrm{T}_{\mathrm{hi}}\right)$, karakteristik penukar panas.

\begin{abstract}
Heat exchangers that are often used in industrial engineering applications are shell and tube types. The mass flow rate at the heat exchanger also influences the characteristics of the heat exchanger. The higher the mass flow rate opposite means the shorter contact time of the two fluids. From this condition, the hypothesis was established that increasing the rate of mass flow opposite would increase the characteristics of a heat exchanger. Experiments were conducted to analyze the effect of temperature variations in the hot fluid at a constant fluid velocity on the characteristics of shell and tube type heat transfer heat exchangers. This study uses hot fluid is oil SAE 10, while cold fluid is fresh water, shell diameter is 4 inch and tube diameter is 3/8 inch with 8 passes tube, cold fluid flows in the shell side and hot fluid flows in tubes with a constant mass flow rate of 0.024 $\mathrm{m} / \mathrm{s}$ with variations in the temperature of the inlet hot fluid (Thi) are $323 \mathrm{~K}, 333 \mathrm{~K}, 343 \mathrm{~K}$, $353 \mathrm{~K}, 363 \mathrm{~K}$. The results showed by Increasing the temperature of the inlet hot fluid (Thi) with a constant velocity (V) affects the heat exchanger characteristics such as Reynold number (Red), Nusselt number (Nud), convection coefficient (h), overall heat transfer coefficient $(U)$, and heat transfer rate $(U) q)$ which increases insignificantly at the temperature of the inlet hot fluid (Thi) $363 \mathrm{~K}$ and the $\min$ at (Thi) $323 \mathrm{~K}$. $\varepsilon$ of the heat exchanger max at Thi $323 \mathrm{~K}$ and then down $1 \%$ at Thi $353 \mathrm{~K}$.
\end{abstract}

Keywords: Heat exchanger, shell and tube, variations of the inlet fluid (Thi), heat exchanger characteristics. 


\section{PENDAHULUAN}

Penukar panas merupakan peralatan yang digunakan untuk perpindahan panas antara dua fluida, dimana keduanya memiliki gradient temperatur dan dipisahkan oleh dinding. Banyak jenis penukar panas yang dibuat dan digunakan dalam pusat pembangkit ketenagaan, sistem ruang pemanas, air conditioning, sistem proses kimia dan lain-lain. Salah satu tipe penukar panas yang sering digunakan dalam aplikasi rekayasa industri yakni tipe shell and tube.

Klasifikasi aransemen aliran fluida dari tipe shell and tube terdiri dari aliran searah (parallel flow), aliran berlawanan (counter flow) dan aliran melintang (cross flow). Penukar panas tipe shell and tube aliran berlawanan (counter flow) fluida panas mengalir dalam pipa (tube) dan fluida dingin mengalir dalam shell. Fluida dingin masuk berlawanan dengan arah masuk dari aliran panas demikian pula dengan aliran keluarnya.

Beberapa penelitian telah dilakukan terkait pengaruh kecepatan fluida, antara lain : Pengaruh kecepatan aliran terhadap keefektivan heat exchanger shell and tube, dengan udara sebagai fluida kerjanya [1]. Fluida udara panas mengalir pada sisi tube dan udara dingin pada sisi shell. Penukar panas tersebut memiliki 7 tube dari tembaga. Hasilnya mendapatkan bahwa efektivitas heat exchanger lebih baik ketika udara panas mengalir pada sisi tube dan udara dingin pada sisi shell. Hal ini dikarenakan kerapatan udara panas lebih rendah maka koefisien panas konveksinya tinggi, sementara luasannya tidak diperbesar. Untuk itu udara panas harus mengalir dengan kecepatan tinggi (di sisi tube).

Penelitian lain yaitu pengaruh perubahan kecepatan fluida pendingin dan pengaruh sifat fisik fluida pendingin terhadap koefisien perpindahan kalor pada penukar kalor shell and tube [2]. Air panas dialirkan melalui tube pada temperatur $60^{\circ} \mathrm{C}$ dengan laju aliran $0,1245 \mathrm{~kg} / \mathrm{s}$, sedangkan fluida pendingin dialirkan melalui shell pada temperatur $42{ }^{\circ} \mathrm{C}$ dengan 6 variasi laju aliran : $0,1012 \mathrm{~kg} / \mathrm{s}$; $0,1115 \mathrm{~kg} / \mathrm{s} ; 0,1285 \mathrm{~kg} / \mathrm{s} ; 0,1390 \mathrm{~kg} / \mathrm{s} ; 0,1495 \mathrm{~kg} / \mathrm{s}$ dan $0,1590 \mathrm{~kg} / \mathrm{s}$. dengan penambahan laju aliran fluida pendingin laju perpindahan kalor yang terjadi akan meningkat sehingga koefisien perpindahan kalor keseluruhan juga akan meningkat.

Pengaruh kecepatan terhadap efektivitas suatu Shell and Tube Heat Exchanger dengan udara sebagai fluida kerja [3],[4]. Dari hasil penelitian didapat bahwa efektivitas naik seiring dengan kenaikan kecepatan hingga suatu harga tertentu dan kemudian akan turun.

Pengaruh Temperatur Fluida Panas
Penelitian terkait karakteristik Alat Penukar Kalor dilakukan dengan penambahan udara ke dalam aliran air panas. Pipa yang digunakan adalah pipa tembaga dengan panjang $0,75 \mathrm{~m}$ dan diameter dalam $0,0153 \mathrm{~m}$. Data pengukuran menunjukkan bahwa menambahan udara ke dalam aliran air panas mencapai $0,50 \mathrm{~kg} / \mathrm{s}$ teridentifikasi panas yang dilepaskan APK fluktuatif dan kecenderungan konstan [5]. Sehingga laju perpindahan panas ke air pendingin menurun drastis. Fenomena tersebut menunjukkan efektivitas APK menurun.

Untuk mengetahui laju perpindahan kalor dilakukan variasi temperatur inlet pada tube dan mengetahui efisiensi efektif pada heat exchanger jenis shell and tube [6]. Dari hasil pengujian didapatkan hasil bahwa jika semakin tinggi nilai faktor kenaikan suhu maka efisiensi Heat exchanger akan semakin meningkat.

Untuk meningkatkan performa penukar panas shell and tube terutama pada penggunaan tipe baffle [7], menggunakan variasi sudut baffle sebesar $0^{\circ}$ sampai $60^{\circ}$ dengan susunan tube tipe staggered. Hasil analisa mengunakan CFD menunjukkan baffle $30^{\circ}$ laju perpindahan panas dan efisiensi tinggi sedangkan baffle dengan sudut $60^{\circ}$ berpengaruh terhadap penurunan tekanan.

Pengaruh kecepatan aliran panas masuk terhadap karateristik heat exchanger shell and tube dengan arah aliran searah dan tanpa baffle, dengan kecepatan aliran divariasikan dari $0.011 \mathrm{~m} / \mathrm{s} \mathrm{hingga}$ $0.037 \mathrm{~m} / \mathrm{s}$ pada temperatur fluida panas masuk sebesar 363K [8]. Hasilnya seiring naiknya kecepatan fluida panas masuk maka karakteristik penukar panas akan meningkat, sedangkan efektifitas heat exchanger $(\varepsilon)$ optimal pada $\mathrm{V}=$ $0.030 \mathrm{~m} / \mathrm{s}$ dan minimum pada $\mathrm{V}=0.011 \mathrm{~m} / \mathrm{s}$.

Pada penelitian ini akan didesain sebuah penukar panas aransemen aliran berlawanan arah (counter flow) tanpa baffle. Jenis aliran yang digunakan aliran turbulen. Mengingat penelitian sebelumnya bahwa Terdapat pengaruh bilangan Reynold dan bilangan Prandtl terhadap karateristik perpindahan panas [9]. Dimana bilangan Prandtl berpengaruh terhadap thermal boundary layer. Thermal boundary layer merupakan hasil dari perbedaan antara temperatur free stream dan temperatur pada permukaan benda. Maka penelitian ini menggunakan fluida air tawar yang akan mengalir pada sisi shell dan fluida oli yang akan mengalir pada sisi tube. Diameter shell 4 inch dan diameter tube $3 / 8$ inch dengan banyaknya tube adalah 8 laluan. Aliran fluida dingin mengalir 
dalam sisi shell dan aliran fluida panas mengalir dalam tube-tube dengan laju aliran massa konstan $0.024 \mathrm{~m} / \mathrm{s}$. Temperatur masuk fluida panas (Thi) divariasikan $323^{\circ} \mathrm{K}, 333^{\circ} \mathrm{K}, 343^{\circ} \mathrm{K}, 353^{\circ} \mathrm{K}, 363^{\circ} \mathrm{K}$ sedangkan temperatur pada sisi shell konstan $\left.301^{\circ} \mathrm{K}\right)$.

Hal ini bertujuan untuk menganalisa secara eksperimen pengaruh variasi temperatur masuk fluida panas pada kecepatan fluida konstan aliran berlawanan terhadap karakteristik perpindahan panas penukar panas tipe shell and tube.

\section{BAHAN DAN METODE}

\subsection{Konsep dan Persamaan Dasar}

Perpindahan panas didefenisikan berpindahnya energi yang terjadi karena adanya perbedaan suhu dimana arah perpindahan terjadi dari benda yang mempunyai temperatur tinggi ke benda yang mempunyai temperatur lebih rendah.

\section{Konveksi}

Merupakan perpindahan energi dalam bentuk panas yang melibatkan perpindahan energi dan massa

$$
q=h . A . \Delta T
$$

\section{Bilangan Reynolds}

Bilangan Reynolds adalah rasio dari gaya inersia dan viskositas dari fluida. Bilangan Reynolds didasarkan pada diameter pipa dan kecepatan ratarata didalam pipa. Dapat ditulis persamaannya sebagai berikut :

\section{Bilangan Nusselt}

$$
R e=\frac{4 m_{h}}{\pi \cdot d_{h} \mu_{h}}
$$

Bilangan Nusselt merupakan parameter koefisien yang dapat dipakai sebagai ukuran karakteristik perpindahan panas yang terjadi. bilangan Nusselt adalah rasio dari konveksi dan konduksi dari fluida. Untuk kondisi turbulen bilangan Nusselt menurut Persamaan Dittus-Boelter dapat ditulis sebagai berikut:

$$
N u=0.023 . R_{D}^{4 / 5} \operatorname{Pr}^{n}
$$

\section{Koefisien Konveksi}

Penentuan koefisien perpindahan panas konveksi untuk temperatur dinding konstan dalam pipa atau silinder dapat menggunakan rumus :

$$
h=N u \frac{k}{d_{i}}
$$

\section{Koefisien Perpindahan Panas Menyeluruh}

Perpindahan panas meliputi 2 aliran fluida yang dipisahkan oleh dinding padat. Panas yang ditransfer pertama dari fluida panas ke dinding secara konveksi sedangkan yang melewati dinding secara konduksi. Dan dari dinding silinder ke fluida dingin secara konveksi.

$$
U=\frac{1}{\left(\frac{1}{h_{i}}\right)+\left(\frac{1}{h_{o}}\right)}
$$

\section{Laju Perpindahan Panas}

Analisis transfer panas pada penukar panas, transfer panas total rata-rata $\mathrm{Q}$ melebihi penukar panas merupakan kwantitas utama. Untuk aliran berlawanan bentuk dari $\Delta \mathrm{Tm}$ sudah digunakan pada keseimbangan energi untuk perbedaan area element dA pada fluida panas dan dingin.

$$
q=U A F \frac{\left[\mathrm{T}_{\mathrm{h}, \mathrm{o}}-\mathrm{T}_{\mathrm{c}}\right]-\left[\mathrm{T}_{\mathrm{h}, \mathrm{i}}-\mathrm{T}_{\mathrm{c}, \mathrm{o}}\right]}{\left[\frac{\left[\mathrm{T}_{\mathrm{h}, \mathrm{o}}-\mathrm{T}_{\mathrm{c}, \mathrm{i}}\right]}{\left[\mathrm{T}_{\mathrm{h}, \mathrm{i}}-\mathrm{T}_{\mathrm{c}, \mathrm{o}}\right]}\right]}
$$

\section{Efektivitas Penukar Kalor}

Untuk kerja penukar kalor yang akan dianalisa adalah karakteristik dari penukar panas, maka perlu diperhatikan pula efektivitas penukar kalor, yaitu

$$
\varepsilon=\frac{Q \text { act }}{Q \max }
$$

\subsection{Prosedur Penelitian}

Prosedur penelitian sebagai berikut :

1) Mempersiapkan perlengkapan dan peralatan yang diperlukan.

2) Memasang instalasi penelitian.

3) Mengisolasi shell dengan glasswoll dan asbes.

4) Memasukkan fluida dingin (air tawar) dan fluida panas (oli) ke masing-masing tangki.

5) Pengecekan pompa sebelum mengalirkan fluida panas dan dingin.

6) Mengatur laju aliran massa fluida panas dan fluida dingin dengan mengatur bukaan katup dan dibaca pada flowmeter untuk mendapat kecepatan $0.024 \mathrm{~m} / \mathrm{s}$ konstan, temperatur masuk fluida panas variasi $323 \mathrm{~K}$.

7) Pengambilan data temperatur ini dilakukan sebanyak lima kali untuk mendapatkan data valid.

8) Ulangi langkah ke-6, untuk temperatur masuk fluida panas dengan variasi temperature 333$363 \mathrm{~K}$. 


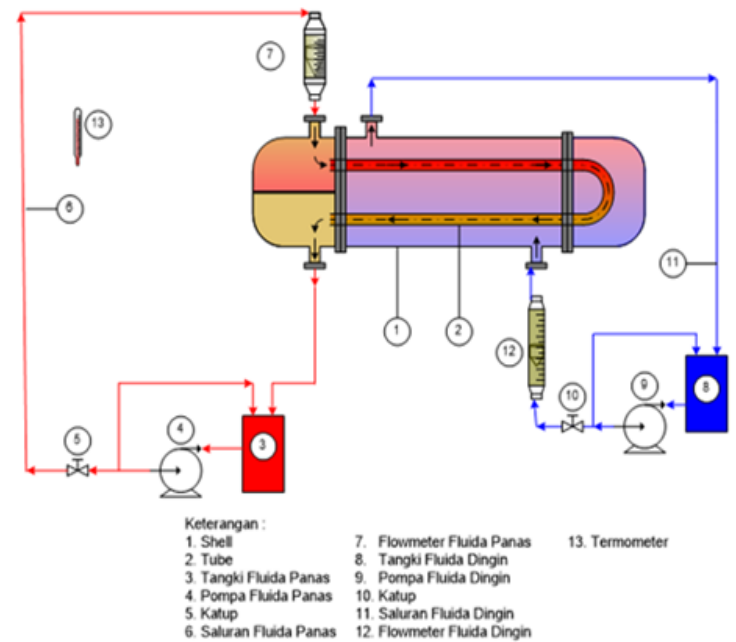

Gambar 2.1. Instalasi Penelitian (gambar menggunakan Microsoft visio)

\section{HASIL DAN PEMBAHASAN}

Pengujian dilakukan dengan memvariasikan temperature masuk fluida panas $\left(\mathrm{T}_{\text {hi }}\right)$ yakni 323$363 \mathrm{~K}$ dan kecepatan fluida (V) $0.024 \mathrm{~m} / \mathrm{s}$ konstan. Pengambilan data dilakukan setelah sistem dalam kondisi steady. Kondisi steady tercapai apabila kecepatan fluida (V) dan temperatur masuk fluida panas $\left(\mathrm{T}_{\text {hi }}\right)$ tidak lagi mengalami fluktuasi yang cukup berarti atau konstan. Pada kondisi steady dilakukan pencatatan temperatur masing-masing: temperatur masuk fluida panas $\left(\mathrm{T}_{\mathrm{hi}}\right)$, temperatur keluar fluida panas $\left(\mathrm{T}_{\mathrm{ho}}\right)$, temperatur masuk fluida dingin $\left(\mathrm{T}_{\mathrm{ci}}\right)$ dan temperatur keluar fluida dingin $\left(\mathrm{T}_{\mathrm{co}}\right)$, diperoleh data sebagai berikut:

Tabel 1. Hasil penelitian

\begin{tabular}{|c|c|c|c|c|}
\hline \multicolumn{3}{|c|}{ Skala : Fluida Panas (Oli) 175, Fluida Dingin } \\
\hline V & Thi & Tho & Tci & Tco \\
\hline \multirow{4}{*}{0.024} & 323 & 313.8 & & 306.4 \\
\cline { 2 - 3 } \cline { 2 - 3 } & 333 & 314.2 & \multirow{4}{*}{301} & 306.8 \\
\cline { 2 - 3 } & 343 & 314.5 & 308.1 \\
\cline { 2 - 3 } & 353 & 314.4 & & 310.8 \\
\cline { 2 - 3 } & 363 & 314.6 & & 312.2 \\
\hline
\end{tabular}

\subsection{Analisa Fluida Panas Masuk}

Hasil eksperimen dengan memvariasikan temperatur masuk fluida panas $(\mathrm{Thi})=323-363 \mathrm{~K}$ dan kecepatan fluida (V) $0.024 \mathrm{~m} / \mathrm{s}$ konstan, memperlihatkan bahwa semakin besar temperatur masuk fluida panas (Thi) dengan kecepatan fluida (V) konstan, maka semakin besar bilangan Reynolds (Redh) kondisi terjadi pada keseluruhan temperatur masuk fluida panas (Thi).

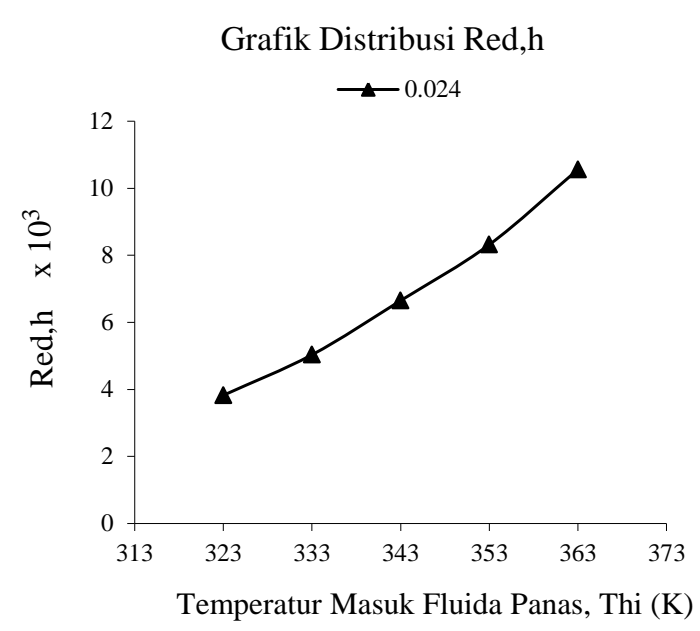

Gambar 3.1. Grafik distribusi $\operatorname{Red}_{\mathrm{h}}$ sebagai fungsi $\mathrm{T}_{\mathrm{hi}}$

Gambar 3.1memperlihatkan kenaikan bilangan Reynold $\left(\operatorname{Red}_{\mathrm{h}}\right)$ tidak signifikan terjadi pada Thi < $333 \mathrm{~K}$ dengan gradien kenaikan landai sedangkan pada Thi > $333 \mathrm{~K}$ kenaikan bilangan Reynold (Redh) cukup signifikan dengan gradien kenaikan curam. Bilangan Reynolds (Redh) terendah pada Thi $=323 \mathrm{~K}$ dan bilangan Reynolds (Redh) optimal pada Thi $=363 \mathrm{~K}$ untuk setiap variasi temperatur masuk fluida panas (Thi).

Fenomena ini berkaitan dengan temperatur fluida panas rerata yang mengalami peningkatan dengan semakin besarnya temperatur masuk fluida panas (Thi), yang menyebabkan viskositas fluida panas semakin menurun, hal ini sesuai pula dengan persamaan bilangan Reynolds dimana bilangan Reynolds merupakan berbanding terbalik dengan viskositas fluida panas $(\mu \mathrm{h})$.

Hasil eksperimen memperlihatkan bahwa semakin besar temperatur masuk fluida panas $\left(\mathrm{T}_{\mathrm{hi}}\right)$ dengan kecepatan fluida (V) konstan, maka semakin besar bilangan Nusselt $\left(\mathrm{Nud}_{\mathrm{h}}\right)$ kondisi terjadi pada keseluruhan temperatur masuk fluida panas $\left(\mathrm{T}_{\text {hi }}\right)$.

Gambar 3.2 kenaikan bilangan Nusselt $\left(\mathrm{Nud}_{\mathrm{h}}\right)$ tidak signifikan terjadi pada $\mathrm{T}_{\mathrm{hi}}<343 \mathrm{~K}$ dengan gradien kenaikan landai sedangkan pada $\mathrm{T}_{\mathrm{hi}}>343$ $\mathrm{K}$ kenaikan bilangan Nusselt $\left(\mathrm{Nud}_{\mathrm{h}}\right)$ cukup signifikan dengan gradien kenaikan curam. Bilangan Nusselt $\left(\mathrm{Nud}_{\mathrm{h}}\right)$ terendah pada $\mathrm{T}_{\mathrm{hi}}=323 \mathrm{~K}$ dan bilangan Nusselt (Nud,h) optimal pada $\mathrm{T}_{\mathrm{hi}}=$ $363 \mathrm{~K}$ untuk setiap variasi temperatur masuk fluida panas

$\left(\mathrm{T}_{\mathrm{hi}}\right)$. 
Grafik Distribusi Nud,h

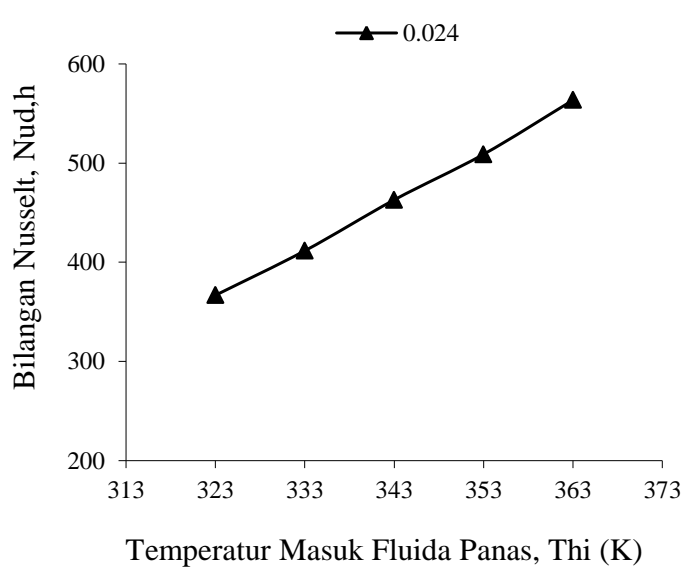

Gambar 3.2. Grafik Distribusi Nudh sebagai fungsi $T_{h i}$

Fenomena ini berkaitan dengan temperatur fluida panas rerata yang mengalami peningkatan dengan semakin besarnya temperatur masuk fluida panas $\left(\mathrm{T}_{\text {hi }}\right)$, yang menyebabkan bilangan Reynold semakin meningkat sehingga bilangan Nusselt juga mengalami peningkatan, hal ini sesuai pula dengan persamaan bilangan Nusselt dimana bilangan Reynold merupakan berbanding lurus dengan bilangan Nusselt (Nud).

Hasil eksperimen menunjukkan bahwa semakin besar temperatur masuk fluida panas (Thi) dengan kecepatan fluida (V) konstan, maka semakin besar koefisien konveksi (hi) kondisi terjadi pada keseluruhan temperatur masuk fluida panas (Thi) seperti diperlihatkan pada gambar 3.3.

Gambar 3.3memperlihatkan kenaikan bilangan koefisien konveksi (hi) tidak signifikan terjadi pada Thi < $343 \mathrm{~K}$ dengan gradien kenaikan landai sedangkan pada Thi > $343 \mathrm{~K}$ kenaikan koefisien konveksi (hi) cukup signifikan dengan gradien kenaikan curam. Koefisien konveksi (hi) terendah pada $\mathrm{Thi}=323 \mathrm{~K}$ dan koefisien konveksi (hi) optimal pada Thi $=363 \mathrm{~K}$ untuk setiap variasi temperatur masuk fluida panas (Thi).

Fenomena ini berkaitan dengan temperatur fluida panas rerata yang mengalami peningkatan dengan semakin besarnya temperatur masuk fluida panas (Thi), yang menyebabkan bilangan Reynolds, bilangan Nusselt semakin meningkat sehingga koefisien konveksi juga mengalami peningkatan, hal ini sesuai pula dengan persamaan bilangan koefisien konveksi dimana koefisien konveksi merupakan berbanding lurus dengan bilangan Nusselt $\left(\mathrm{Nu}_{\mathrm{dh}}\right)$.

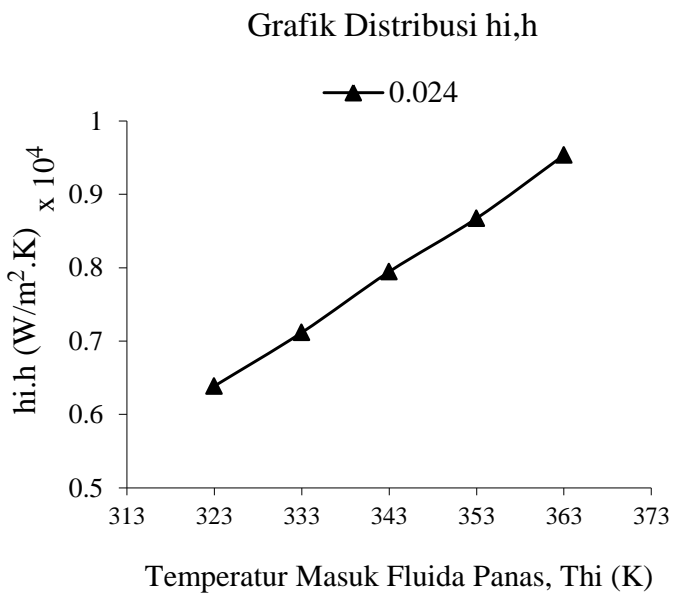

Gambar 3.3. Grafik distribusi hi sebagai fungsi Thi

\subsection{Analisa Fluida Dingin}

Hasil eksperimen memperlihatkan bahwa semakin besar temperatur masuk fluida panas (Thi) dengan kecepatan fluida (V) konstan, maka semakin besar bilangan Reynold (Redc) kondisi terjadi pada keseluruhan temperatur masuk fluida panas (Thi) seperti diperlihatkan pada gambar 3.4

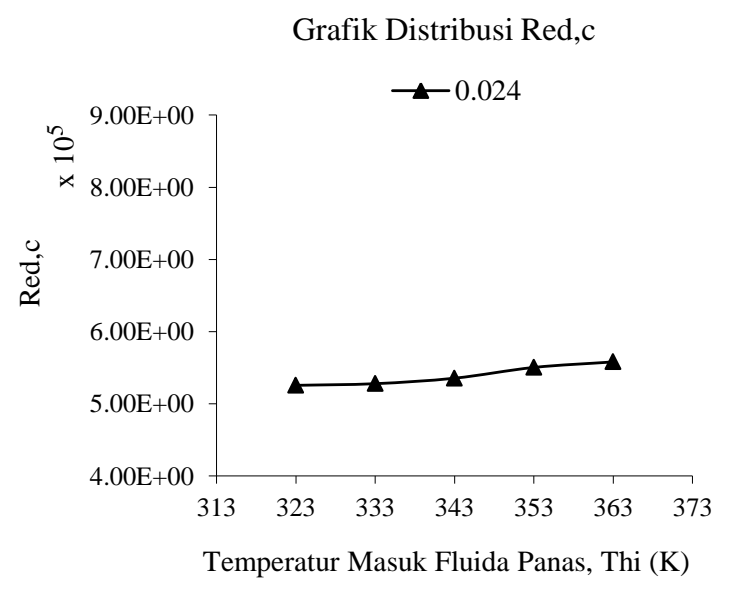

Gambar 3.4. Grafik distribusi $\operatorname{Red}_{\mathrm{c}}$ sebagai fungsi $T_{h i}$

Gambar 3.4, memperlihatkan kenaikan bilangan Reynold (Red,c) cukup signifikan terjadi pada Thi $<353 \mathrm{~K}$ dengan gradien kenaikan curam sedangkan pada Thi > $353 \mathrm{~K}$ kenaikan bilangan Reynold (Red,c) tidak signifikan dengan gradien kenaikan landai. Bilangan Nusselt (Red,c) terendah pada Thi $=323 \mathrm{~K}$ dan bilangan Nusselt (Nudc) optimal pada Thi $=363 \mathrm{~K}$ untuk setiap variasi temperatur masuk fluida panas.

Fenomena ini berkaitan dengan temperatur fluida dingin rerata yang mengalami peningkatan dengan semakin besarnya temperatur masuk fluida panas (Thi), yang menyebabkan viskositas fluida 
dingin semakin menurun, hal ini sesuai pula dengan persamaan bilangan Reynold dimana bilangan Reynold merupakan berbanding terbalik dengan viskositas fluida dingin $\left(\mu_{\mathrm{c}}\right)$

Hasil eksperimen memperlihatkan bahwa semakin besar temperatur masuk fluida panas (Thi) dengan kecepatan fluida (V) konstan, maka semakin besar bilangan Nusselt (Nudc) kondisi terjadi pada keseluruhan temperatur masuk fluida panas (Thi) seperti diperlihatkan pada gambar 3.5.

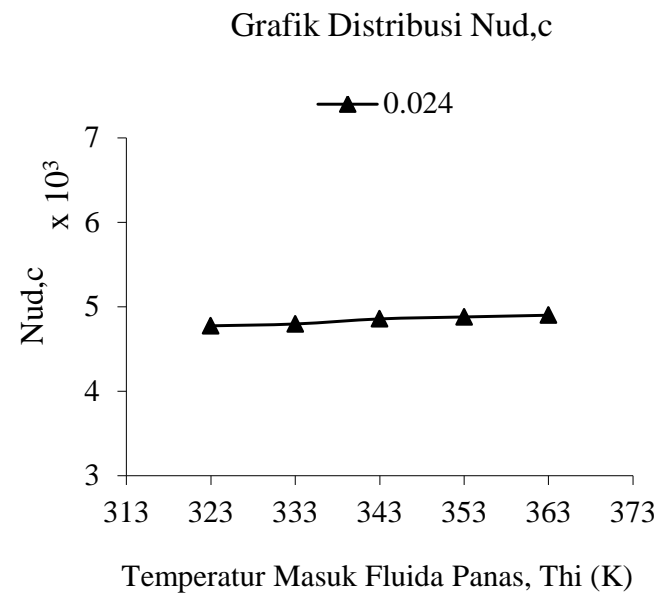

$$
\begin{gathered}
\text { Gambar 3.5. Grafik distribusi } \mathrm{Nu}_{\mathrm{dc}} \\
\text { sebagai fungsi } \mathrm{T}_{\mathrm{hi}}
\end{gathered}
$$

Gambar 3.5, memperlihatkan kenaikan bilangan Nusselt $\left(\mathrm{Nud},{ }_{\mathrm{c}}\right.$ ) signifikan terjadi pada Thi < $343 \mathrm{~K}$ dengan gradien kenaikan curam sedangkan pada Thi > $343 \mathrm{~K}$ kenaikan bilangan Nusselt (Nud,c) tidak signifikan dengan gradien kenaikan landai. Bilangan Nusselt (Nud,c) terendah pada Thi $=323$ $\mathrm{K}$ dan bilangan Nusselt (Nudc) optimal pada Thi $=$ $363 \mathrm{~K}$ untuk setiap variasi temperatur masuk fluida panas (Thi).

Fenomena ini berkaitan dengan temperatur fluida dingin rerata yang mengalami peningkatan dengan semakin besarnya temperatur masuk fluida panas $\left(\mathrm{T}_{\mathrm{hi}}\right)$, yang menyebabkan bilangan Reynolds semakin meningkat sehingga bilangan Nusselt juga mengalami peningkatan.Hal ini sesuai pula dengan persamaan bilangan Nusselt dimana bilangan Reynold merupakan berbanding lurus dengan bilangan Nusselt $\left(\mathrm{Nu}_{\mathrm{dc}}\right)$.

Hasil eksperimen memperlihatkan bahwa semakin besar temperatur masuk fluida panas (Thi) dengan kecepatan fluida (V) konstan, maka semakin besar koefisien konveksi (ho) kondisi terjadi pada keseluruhan temperatur masuk fluida panas (Thi) seperti diperlihatkan pada gambar 3.6.

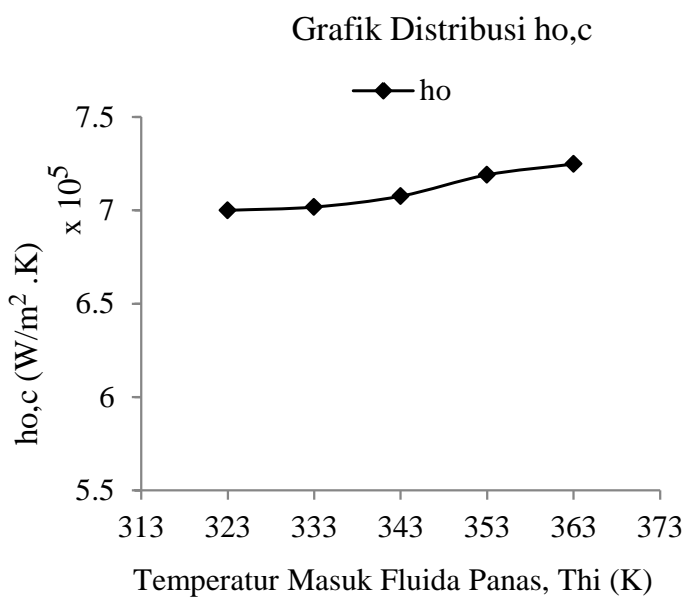

Gambar 3.6. Grafik distribusi $h_{o}$ sebagai fungsi $T_{h i}$

Gambar 3.6, memperlihatkan kenaikan bilangan koefisien konveksi (ho) cukup signifikan terjadi pada Thi $<353 \mathrm{~K}$ dengan gradien kenaikan curam sedangkan pada Thi > $353 \mathrm{~K}$ kenaikan koefisien konveksi (ho) tidak signifikan dengan gradien kenaikan landai. Koefisien konveksi (ho) terendah pada $\mathrm{Thi}=323 \mathrm{~K}$ dan koefisien konveksi (ho) optimal pada Thi $=363 \mathrm{~K}$ untuk setiap variasi temperatur masuk fluida panas (Thi).

Fenomena ini berkaitan dengan temperatur fluida dingin rerata yang mengalami peningkatan dengan semakin besarnya temperatur masuk fluida panas $\left(\mathrm{T}_{\text {hi }}\right)$, yang menyebabkan bilangan Reynold, bilangan Nusselt mengalami peningkatan sehingga koefisien konveksi juga mengalami peningkatan, hal ini sesuai pula dengan persamaan koefisien konveksi dimana koefisien konveksi merupakan berbanding lurus dengan bilangan $\mathrm{Nusselt}\left(\mathrm{Nu}_{d, c}\right)$.

\subsection{Analisa Koefisien Perpindahan Panas Menyeluruh}

Hasil eksperimen memperlihatkan bahwa semakin besar temperatur masuk fluida panas $\left(\mathrm{T}_{\mathrm{hi}}\right)$ dengan kecepatan fluida (V) konstan, maka semakin besar koefisien perpindahan panas menyeluruh (U) kondisi terjadi pada keseluruhan temperatur masuk fluida panas ( $\left.\mathrm{T}_{\text {hi }}\right)$ seperti diperlihatkan pada gambar 3.7.

Gambar 3.7, memperlihatkan kenaikan koefisien perpindahan panas menyeluruh (U) tidak signifikan terjadi pada $\mathrm{T}_{\text {hi }}>333 \mathrm{~K}$ dengan gradien kenaikan landai sedangkan pada $\mathrm{T}_{\text {hi }}<333 \mathrm{~K}$ kenaikan koefisien perpindahan panas menyeluruh (U) cukup signifikan dengan gradien kenaikan curam. Koefisien perpindahan panas menyeluruh (U) terendah pada $\mathrm{T}_{\mathrm{hi}}=323 \mathrm{~K}$ dan koefisien 
perpindahan panas menyeluruh (U) optimal pada $\mathrm{T}_{\mathrm{hi}}=363 \mathrm{~K}$ untuk setiap variasi temperatur masuk fluida panas $\left(\mathrm{T}_{\mathrm{hi}}\right)$.

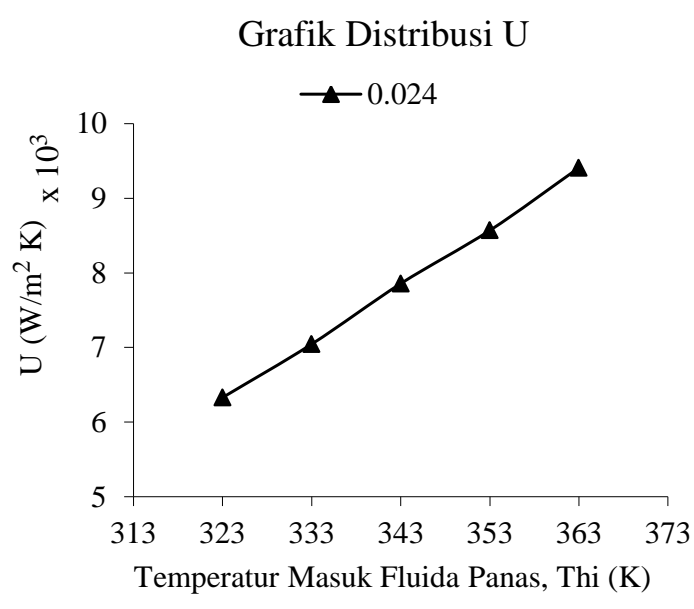

Gambar 3.7. Grafik distribusi U sebagai fungsi $\mathrm{T}_{\mathrm{hi}}$

Fenomena ini berkaitan dengan temperatur fluida dingin dan panas rerata yang mengalami peningkatan dengan semakin besarnya temperatur masuk fluida panas $\left(\mathrm{T}_{\mathrm{hi}}\right)$ yang menyebabkan bilangan Reynold semakin meningkat sehingga bilangan Nusselt, koefisien konveksi juga mengalami peningkatan sehingga koefisien perpindahan panas menyeluruh (U) mengalami peningkatan, hal ini sesuai pula dengan persamaan koefisien perpindahan panas menyeluruh (U) dimana koefisien konveksi merupakan berbanding lurus dengan koefisien perpindahan panas menyeluruh (U).

\subsection{Analisa Laju Perpindahan Panas}

Hasil eksperimen memperlihatkan bahwa semakin besar temperatur masuk fluida panas $\left(\left(\mathrm{T}_{\mathrm{hi}}\right)\right.$ dengan kecepatan fluida (V) konstan,maka semakin besar laju perpindahan panas (q) kondisi terjadi pada keseluruhan temperatur masuk fluida panas ( $\left.\mathrm{T}_{\mathrm{hi}}\right)$ seperti diperlihatkan pada gambar 3.8.

Gambar 3.8, memperlihatkan kenaikan laju perpindahan panas (q) cukup signifikan terjadi pada $\mathrm{T}_{\text {hi }}<333 \mathrm{~K}$ dan $\mathrm{T}_{\text {hi }}>353 \mathrm{~K}$ dengan gradien kenaikan curam sedangkan pada $333<\mathrm{T}_{\text {hi }}<353 \mathrm{~K}$ kenaikan laju perpindahan panas (q) tidak signifikan dengan gradien kenaikan landai. Laju perpindahan panas (q) terendah pada $\mathrm{T}_{\mathrm{hi}}=323 \mathrm{~K}$ dan laju perpindahan panas (q) optimal pada $\mathrm{T}_{\mathrm{hi}}=$ $363 \mathrm{~K}$ untuk setiap variasi temperatur masuk fluida panas $\left(\mathrm{T}_{\mathrm{hi}}\right)$.

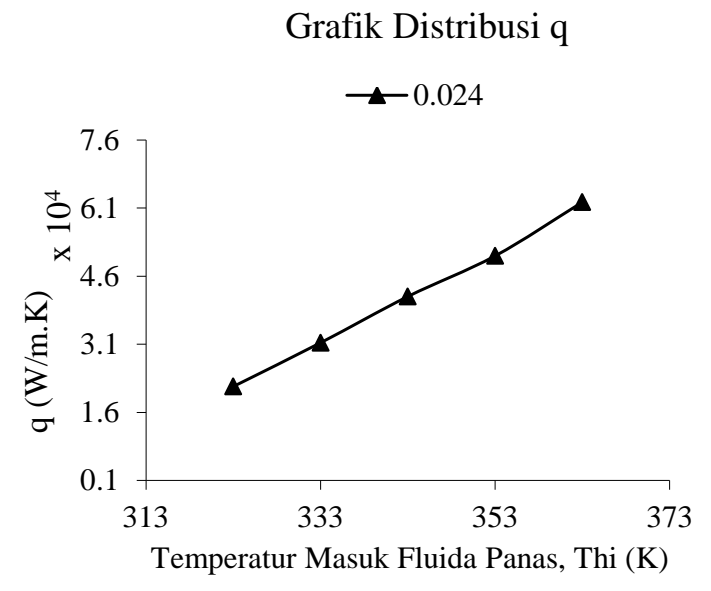

Gambar 3.8. Grafik distribusi q sebagai fungsi $\mathrm{T}_{\mathrm{hi}}$

Fenomena ini berkaitan dengan temperatur fluida dingin dan panas rerata yang mengalami peningkatan dengan semakin besarnya temperatur masuk fluida panas $\left(\mathrm{T}_{\mathrm{hi}}\right)$, yang menyebabkan bilangan Reynold, bilangan Nusselt, koefisien konveksi dan koefisien perpindahan panas menyeluruh (U) mengalami peningkatan, hal ini sesuai pula dengan persamaan laju perpindahan panas (q) dimana laju perpindahan panas (q) merupakan berbanding lurus dengan koefisien perpindahan panas menyeluruh (U) dan $\varepsilon \mathrm{T}_{\text {lmtd. }}$.

\subsection{Analisa Efektivitas Penukar Panas}

Hasil eksperimen memperlihatkan bahwa semakin besar temperatur masuk fluida panas $\left(\mathrm{T}_{\mathrm{hi}}\right)$ dengan kecepatan fluida (V) konstan, maka semakin kecil efektivitas $(\varepsilon)$ kondisi terjadi pada keseluruhan temperatur masuk fluida panas $\left(T_{h i}\right)$. Jika dibandingkan dengan penelitian yang telah dilakukan oleh Nicolas Titahelu [8], maka hasilnya memiliki kesamaan yaitu penurunan nilai efektivitas akibat laju perpindahan panas aliran fluida.

Fenomena ini menunjukan bahwa tingkat kenaikan temperatur fluida panas masuk tidak signifikan jika dibandingkan dengan tingkat kenaikan laju perpindahan panas maximum, hal ini sesuai pula dengan persamaan efektivitas $(\varepsilon)$ dimana laju perpindahan panas (q) merupakan berbanding lurus dengan efektivitas $(\varepsilon)$ sedangkan laju perpindahan panas maximum (qmax) berbanding terbalik. 


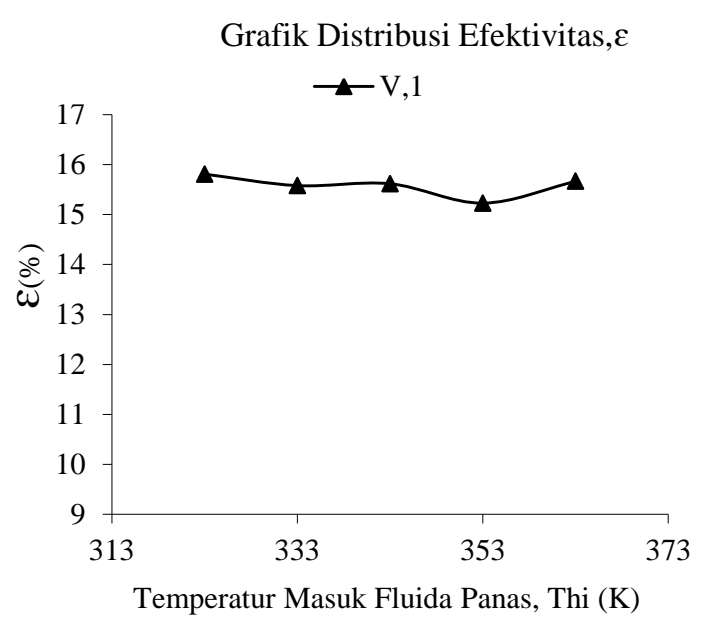

Gambar 3.9. Grafik distribusi $\epsilon$ sebagai fungsi $\mathrm{T}_{\mathrm{hi}}$

\section{KESIMPULAN}

Sesuai hasil penelitian yang dilakukan dengan memvariasikan temperatur masuk fluida panas $\left(\mathrm{T}_{\mathrm{hi}}\right)$ yakni 323-363 K dengan kecepatan fluida konstan $0.024 \mathrm{~m} / \mathrm{s}$ pada penukar panas shell and tube yaitu Peningkatan temperatur fluida panas masuk $\left(T_{h i}\right)$ dengan kecepatan (V) konstan mempengaruhi karakteristik penukar panas seperti bilangan Reynold $\left(\mathrm{Re}_{\mathrm{d}}\right.$ ), bilangan Nusselt (Nud), koefisien konveksi (h), koefisien perpindahan panas menyeluruh (U), dan laju perpindahan panas (q) yang meningkat tidak signifikan pada temperatur masuk fluida panas $\left(\mathrm{T}_{\mathrm{hi}}\right) 363 \mathrm{~K}$ dan minimum pada temperatur masuk fluida panas $\left(\mathrm{T}_{\mathrm{hi}}\right) 323 \mathrm{~K}$. Efektivitas penukar panas maksimum pada $\mathrm{T}_{\mathrm{hi}}$ $323 \mathrm{~K}$ dan kemudian turun $1 \%$ pada $\mathrm{T}_{\text {hi }} 353 \mathrm{~K}$.

\section{DAFTAR PUSTAKA}

[1] Ekadewi, Anggraini. Handoyo, "Pengaruh Kecepatan Aliran Terhadap Efektivitas Shell And Tube Heat Exchanger", Jurnal Teknik Mesin Universitas Kristen Petra, Surabaya, 2000.

[2] Lazim, M, "Pengaruh Kecepatan dan Sifat Fluida Pendingin Terhadap Koefisien Perpindahan Kalor Pada Penukar Kalor Shell And Tube", Jurnal Desiminasi Teknologi, Volume 1, Nomor 1, Januari 2013, Hal 50-58.

[3] Aprilno, Kurnia Iqbal, "Pengaruh Kecepatan Terhadap Efisiensi Alat penukar Panas," Undergraduate thesis, UNDIP, 2016.

[4] Puspita Dewi, Meike," Pengaruh Kecepatan Fl uida Terhadap Nilai Efektivitas pada Heat Exc hanger Tipe Shell and Tube," Undergraduate t hesis, UNDIP, 2016

[5] Mahmuddin, M, Syahrir, "Karakteristik Perpindahan Panas Pada Pipa Penukar Kalor
Selongsong Aliran Searah Vertikal”. Journal Of Chemical Process Engineering, Vol 01, No 02, Nov 2016.

[6] Furqan, M, Syukran, Sariyusda, "Kaji Eksperimental dan Analisa Penukar Panas Udara Type Shell And Tube Jenis Aliran Berlawanan", Jurnal Mesin Sains Terapan, Vol.4 No.1, Febuari 2020.

[7] Mostafa, Ahmed. A. H, et all, "Shell and Tube Exchanger Perfomance”, AIAA Propulsion and Energy Forum., AIAA 2017-5026. July 2017.

[8] Titahelu, Nicolas, “Analisis Pengaruh Kecepatan Fluida Panas Aliran Searah Terhadap Karakteristik Heat Exchanger Shell And Tube", Reasearchgate, May 2019.

[9] Tupamahu, S.E, Cendy, "Study Numerik Pengaruh Variasi Bilangan Reynold dan Bilangan Prandtl Terhadap Karakteristik Aliran Fluida dan Perpindahan Panas Melintasi Silinder Sirkular Tunggal”, Jurnal Teknologi, April 2016. 